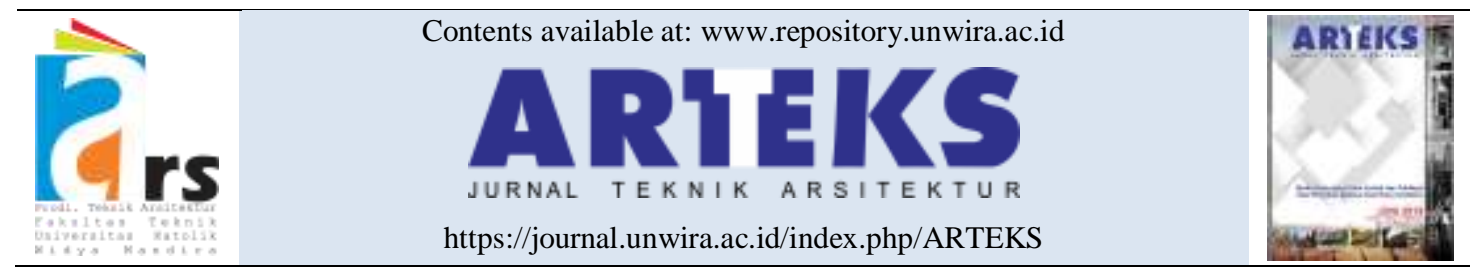

Research paper

doi: $10.30822 /$ arteks.v6i2.559

\title{
Evaluation of pedestrian paths feasibility in the area around Manggarai to support the transit-oriented development concept
}

\section{Muhammad Faleri Febriyanto, Yohanes Karyadi Kusliansjah , Rumiati Rosaline Tobing*(D)}

Department of Architecture, Faculty of Engineering, Universitas Katolik Parahyangan Jl. Ciumbuleuit, no. 94, Bandung, Indonesia

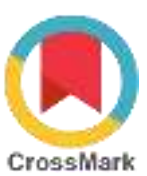

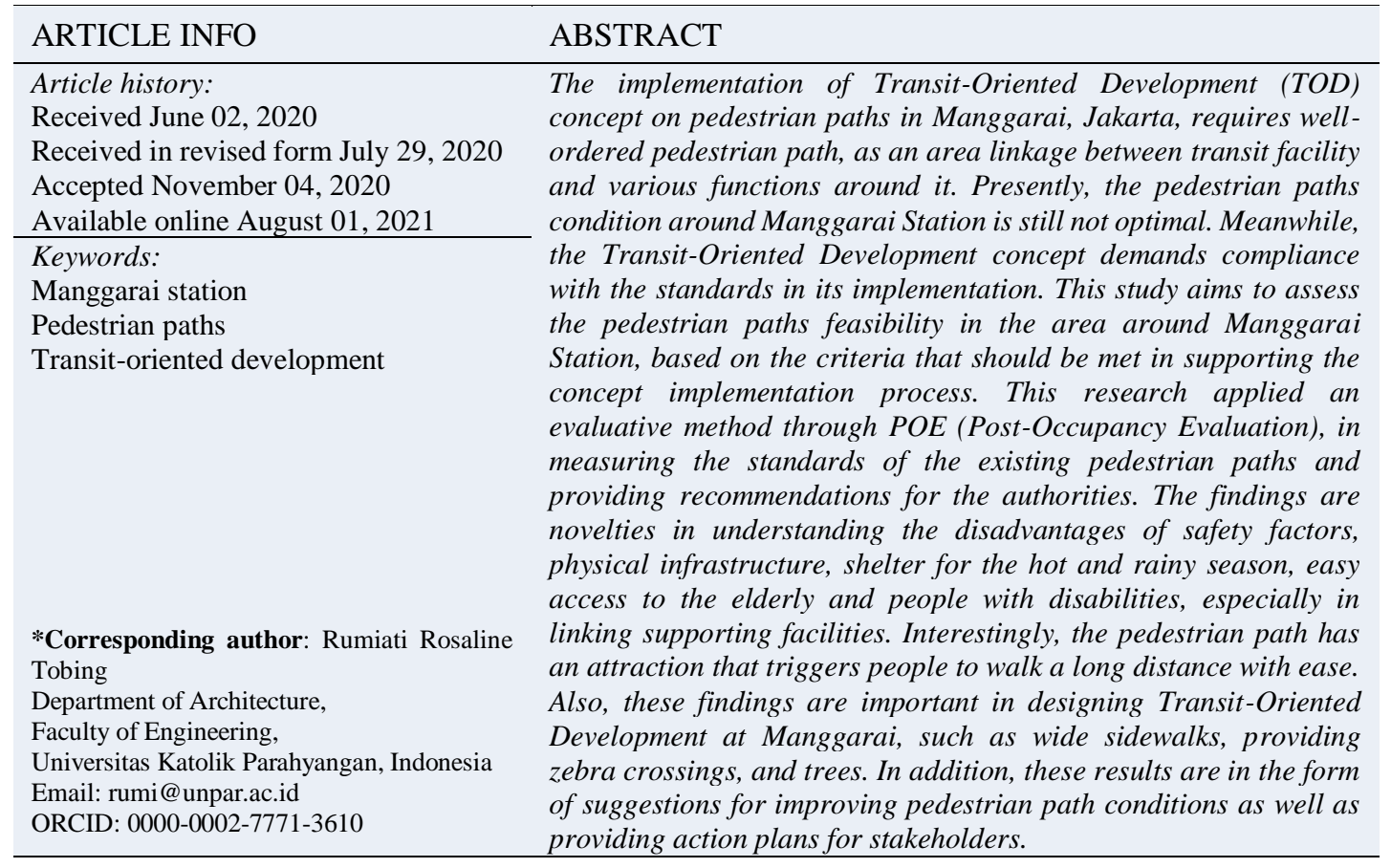

\section{Introduction}

The transit-oriented development concept is one of the efforts made by the Jakarta Provincial Government in overcoming congestion problems (Mungkasa 2018). It is the development of a compact and mixed up areas within the walking distance from commercial center and public transport service points (Alvinsyah 2016).

Manggarai is a village in South Jakarta that is being developed with the transit-oriented development concept (Novianto 2016). The implementation of this concept in this region requires well-ordered pedestrian paths as an area linkage (Pemerintah Provinsi DKI Jakarta 2012).

According to Jayanti (2017), the condition of the pedestrian paths around Manggarai Station is still not optimal (Jayanti 2017). This is not in line with the transit-oriented development concept which prioritizes movement on foot. Furthermore, disturbance on the pedestrian paths cause difficulties for vehicles to move, resulting to congestion around Manggarai Station, due to the people switching to the vehicle path.

The purpose of this study is to evaluate the pedestrian paths feasibility in the areas around Manggarai Station, as a support for the transit- 
oriented development concept by measuring the extent to which the required standards are met, and recommending the steps needed to be taken by the authorities in meeting these criteria.

\section{Method}

The Post-Occupancy Evaluation (POE) method was used to evaluate the pedestrian paths feasibility in the areas around Manggarai Station. This method was carried out by observing the existing conditions and comparing it with the reference criteria set by the Institute for Transportation and Development Policy (2017), as well as the government standards. This research focused on: (1) The existing conditions of the pedestrian paths around Manggarai Station were observed from the physical aspect.; (2) Comparing pedestrian path ideal criteria according to government standards and theories; (3) Recommended actions, plans or policies that need to be carried out by stakeholders.

Primary data in the form of pedestrian conditions were obtained from field observations. Photographs of fields were obtained from direct documentation and google street view at the research location to obtain the existing situation. The sliced images collected from field observations were redrawn by computer, and were used to determine the size and relationship of the pedestrian path with the vehicle lane. The area map image and its current condition were obtained from the Jakarta Province City Planning Office, using satellite imagery tracing results, which were utilized in the broad overview of the pedestrian path linkage.

The secondary data involved the criteria obtained from literature studies and government standards, and included (Institute For Transportation And Development Policy 2017; Kementerian Pekerjaan Umum dan Perumahan Rakyat 2014; 2018; Wijaya and Sari 2020; Sirait, Naibaho, and Aritonang 2018; Setiawan and Ikaputra 2020): (1) The pedestrian path should be safe, complete, and accessible to all groups, in order to ensure its users' safety; (2) Pedestrian paths should be unobstructed, unbroken, continuous (not intermittent), free of obstacles, and connected to a network of transit points; (3) Pedestrian crossing should be accessible to all groups. The minimum width of the road should be 2 meters and given a dividing line; (4) The building facade should be active and alive for walking to be attractive and safe. When the sidewalk becomes busy and visually active, it should be equipped with various activities and media interactions, such as restaurants and shops; (5) There should be elements of shade and protection from sun and rain to increase the desire to walk with ease. This shade should be in the form of trees, construction of buildings such as arcades, canopies, and other elements.

\section{Result and discussion}

The scope of the Transit-Oriented Development area was at a radius of 350 meters from the transit point (Pemerintah Pusat DKI Jakarta 2017). Based on observations, the roads within 350 radius were divided into four types:

1. Primary artery road

Roads such as Tambak and Sultan Agung street do not have direct access to the station, which should be via a secondary collector path. This type of primary arterial road has access to Manggarai Terminal (figures 1, 2, and 3).

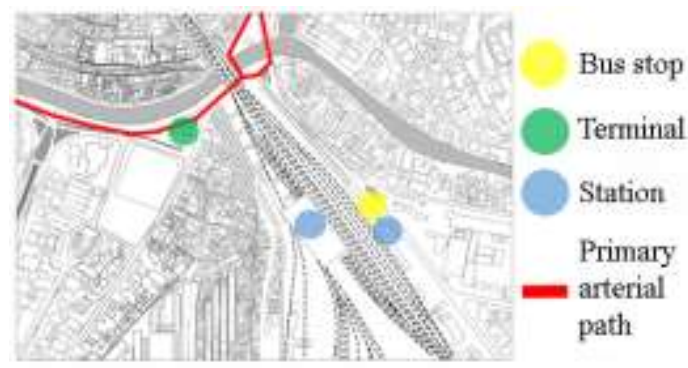

Figure 1. The location map of primary arterial roads

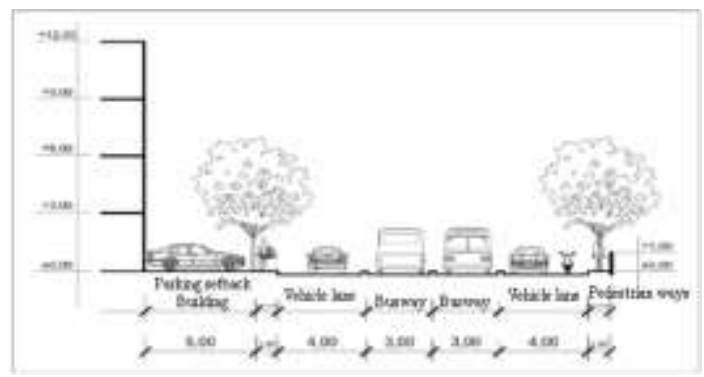

Figure 2. The intersection of primary arterial road at Sultan Agung Street 

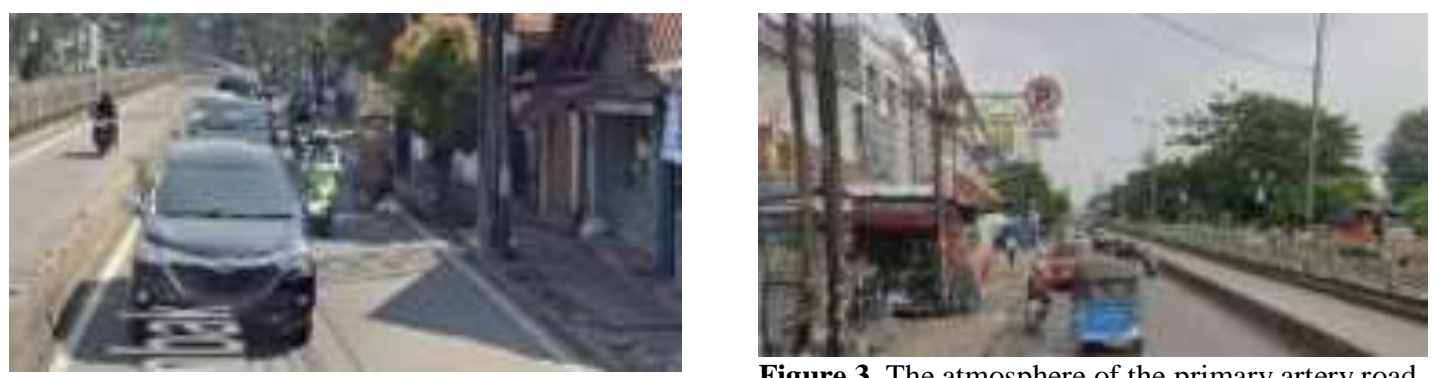

Figure 3. The atmosphere of the primary artery road

Table 1 showed the evaluation results of the pedestrian paths condition that were on the primary arterial road type, based on the criteria set.

Table 1. Conditions of pedestrian paths on primary arterial roads

\begin{tabular}{|c|c|c|c|c|}
\hline $\begin{array}{l}\text { Pedestrian path } \\
\text { criteria }\end{array}$ & Field conditions & Analysis & $\begin{array}{l}\text { Conclusion } \\
\text { conditions }\end{array}$ & Recommendation \\
\hline $\begin{array}{l}\text { Pedestrians } \\
\text { protected from } \\
\text { vehicles. }\end{array}$ & $\begin{array}{l}\text { The sidewalk was higher than the } \\
\text { vehicle road }\end{array}$ & $\begin{array}{l}\text { Safe because the } \\
\text { sidewalk was higher } \\
\text { than the vehicle lane. }\end{array}$ & $\begin{array}{l}\text { Met sidewalk } \\
\text { safety criteria. }\end{array}$ & Maintainable. \\
\hline $\begin{array}{l}\text { Completed } \\
\text { pedestrian path. }\end{array}$ & - There was a street light & $\begin{array}{l}\text { Incomplete, because } \\
\text { there was lighting, } \\
\text { however, no guide } \\
\text { for low vision } \\
\text { people. }\end{array}$ & $\begin{array}{l}\text { Did not meet the } \\
\text { criteria for the } \\
\text { completeness of } \\
\text { the pedestrian } \\
\text { path. }\end{array}$ & $\begin{array}{l}\text { Need to add a low } \\
\text { vision person } \\
\text { guide. }\end{array}$ \\
\hline
\end{tabular}




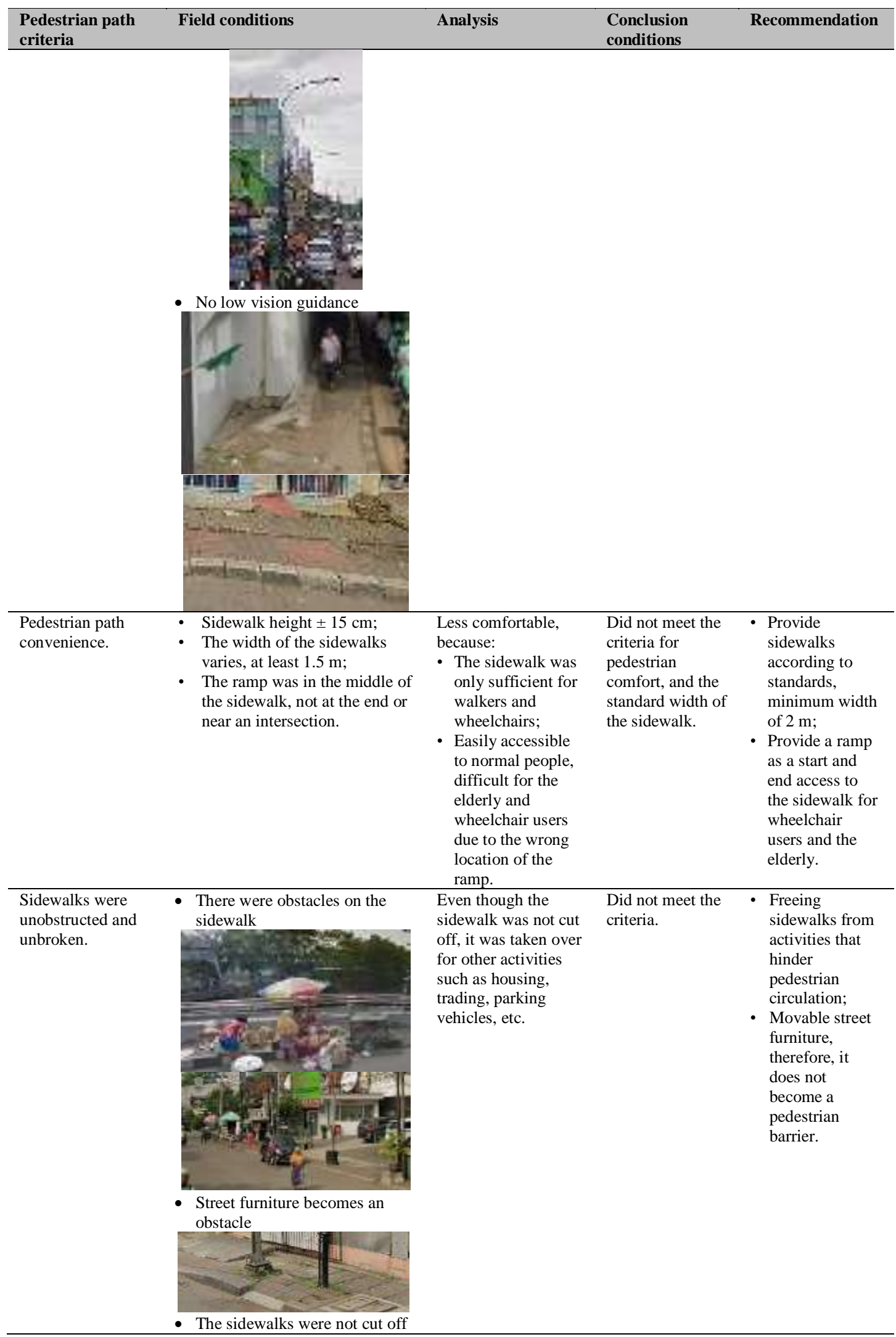




\begin{tabular}{|c|c|c|c|c|}
\hline $\begin{array}{l}\text { Pedestrian path } \\
\text { criteria }\end{array}$ & Field conditions & Analysis & $\begin{array}{l}\text { Conclusion } \\
\text { conditions }\end{array}$ & Recommendation \\
\hline $\begin{array}{l}\text { Pedestrian } \\
\text { crossing. }\end{array}$ & $\begin{array}{l}\text { - There was a zebra crossing to } \\
\text { cross the road junction }\end{array}$ & $\begin{array}{l}\text { Even though it } \\
\text { already has crossing } \\
\text { facilities, it was } \\
\text { difficult for } \\
\text { wheelchair users to } \\
\text { access, because there } \\
\text { were no ramps on } \\
\text { the sidewalks and } \\
\text { pedestrian bridges. }\end{array}$ & $\begin{array}{l}\text { Did not meet the } \\
\text { criteria for } \\
\text { pedestrian } \\
\text { crossing. }\end{array}$ & $\begin{array}{l}\text { Provide a ramp } \\
\text { as access for } \\
\text { wheelchair } \\
\text { users from the } \\
\text { sidewalk to the } \\
\text { zebra crossing; } \\
\text { - Provide ramps } \\
\text { for pedestrian } \\
\text { bridges. }\end{array}$ \\
\hline $\begin{array}{l}\text { Has shade and } \\
\text { protection. }\end{array}$ & $\begin{array}{l}\text { There was a tree on the edge of } \\
\text { the sidewalk } \\
\text { There were plants used to filter } \\
\text { dust on the sidewalk }\end{array}$ & $\begin{array}{l}\text { Inadequate because: } \\
\text { - The trees were far } \\
\text { apart and did not } \\
\text { act as a shade; } \\
\text { - Plants filtered dust } \\
\text { unevenly along the } \\
\text { primary artery } \\
\text { path. }\end{array}$ & $\begin{array}{l}\text { Did not meet the } \\
\text { shading and } \\
\text { protective } \\
\text { criteria. }\end{array}$ & $\begin{array}{l}\text { Replacing with } \\
\text { shade trees; } \\
\text { Increase the } \\
\text { number of trees, } \\
\text { therefore, the } \\
\text { sidewalks are } \\
\text { shaded; } \\
\text { - Provide arcades } \\
\text { in buildings on } \\
\text { the edge of the } \\
\text { sidewalk. }\end{array}$ \\
\hline
\end{tabular}

2. Secondary collectore road type

These road types included North Manggarai, Minangkabau, and Sahardjo streets. North Manggarai street has direct access to the station, not to the Manggarai Terminal (figures 4, 5, and $6)$.

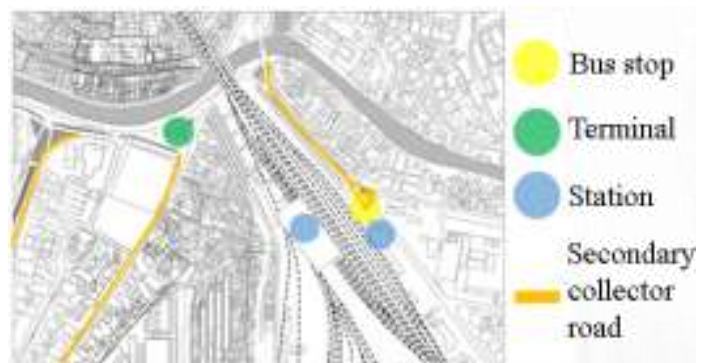

Figure 4. Map of secondary collector road location

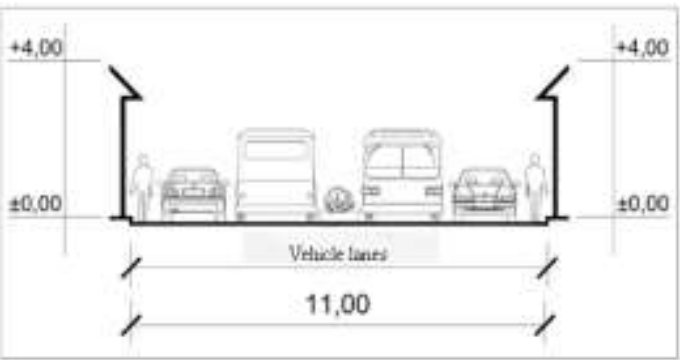

Figure 5. The intersection of the secondary collector road on North Manggarai Street
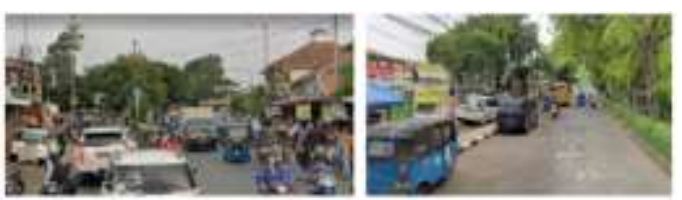

Figure 6. The atmosphere of the secondary collector's road 
Table 2 showed the evaluation results of the pedestrian paths condition, on the secondary collector arterial road type, based on the established criteria.

Table 2. Pedestrian path condition on the secondary collector road

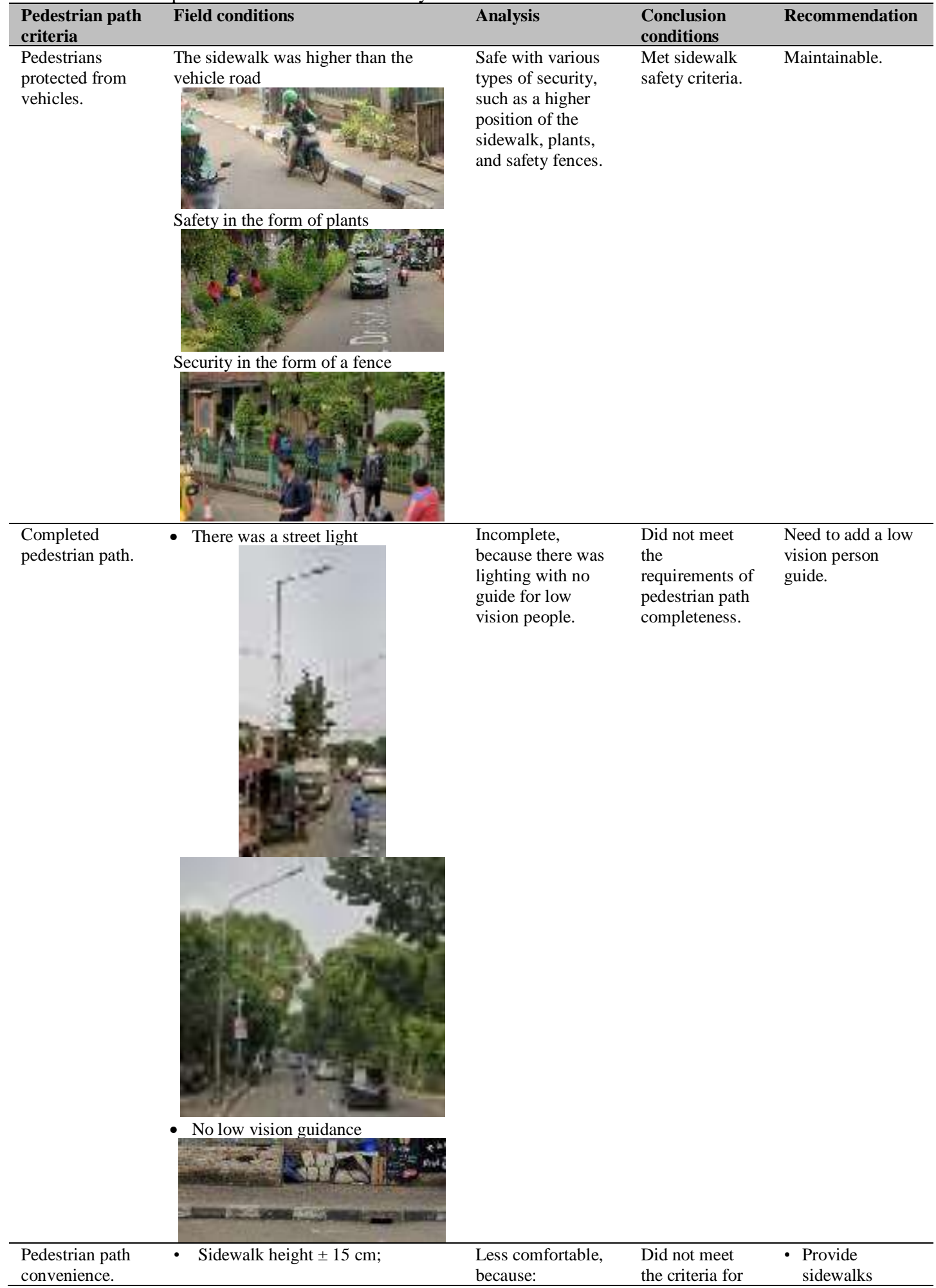




\begin{tabular}{|c|c|c|c|c|}
\hline $\begin{array}{l}\text { Pedestrian path } \\
\text { criteria }\end{array}$ & Field conditions & Analysis & $\begin{array}{l}\text { Conclusion } \\
\text { conditions }\end{array}$ & Recommendation \\
\hline & $\begin{array}{l}\text { The width of the sidewalks varies, } \\
\text { at least } 1.5 \mathrm{~m} \text {; } \\
\text { The ramp was in the middle of the } \\
\text { sidewalk, not at the end or near the } \\
\text { intersection. }\end{array}$ & $\begin{array}{l}\text { The sidewalk } \\
\text { was wide } \\
\text { enough for } \\
\text { walking and } \\
\text { wheelchairs; } \\
\text { Easily accessible } \\
\text { to normal } \\
\text { people, difficult } \\
\text { for the elderly } \\
\text { and wheelchair } \\
\text { users due to the } \\
\text { wrong location } \\
\text { of the ramp. }\end{array}$ & $\begin{array}{l}\text { pedestrian } \\
\text { comfort, and the } \\
\text { standard width } \\
\text { of the sidewalk. }\end{array}$ & $\begin{array}{l}\text { according to } \\
\text { standards, } \\
\text { minimum width } \\
\text { of } 2 \text { m; } \\
\text { - Provide a ramp } \\
\text { as a start and } \\
\text { end access to } \\
\text { the sidewalk for } \\
\text { wheelchair } \\
\text { users and the } \\
\text { elderly. }\end{array}$ \\
\hline $\begin{array}{l}\text { Sidewalks were } \\
\text { unobstructed and } \\
\text { unbroken. }\end{array}$ & $\begin{array}{l}\text { - There were obstacles on the } \\
\text { sidewalk }\end{array}$ & $\begin{array}{l}\text { Although the } \\
\text { sidewalk was not } \\
\text { cut off, it was } \\
\text { taken over for } \\
\text { other activities, } \\
\text { such as housing, } \\
\text { trading, parking } \\
\text { vehicles, etc. }\end{array}$ & $\begin{array}{l}\text { Did not meet } \\
\text { the criteria. }\end{array}$ & $\begin{array}{l}\text { - Freeing } \\
\text { sidewalks from } \\
\text { activities that } \\
\text { hinder } \\
\text { pedestrian } \\
\text { circulation; } \\
\text { - Move trees and } \\
\text { street furniture } \\
\text { in order not to } \\
\text { become a } \\
\text { pedestrian } \\
\text { barrier. }\end{array}$ \\
\hline $\begin{array}{l}\text { Pedestrian } \\
\text { crossing. }\end{array}$ & $\begin{array}{l}\text { - There was not crossing facility at } \\
\text { the intersection }\end{array}$ & $\begin{array}{l}\text { Did not meet the } \\
\text { criteria because } \\
\text { there was no } \\
\text { crossing facilities. }\end{array}$ & $\begin{array}{l}\text { Did not meet } \\
\text { the criteria. }\end{array}$ & $\begin{array}{l}\text { Provide zebra } \\
\text { crossing } \\
\text { especially in } \\
\text { front of } \\
\text { Manggarai } \\
\text { Station; } \\
\text { Provide a ramp } \\
\text { as access for } \\
\text { wheelchair } \\
\text { users from the } \\
\text { sidewalk to the } \\
\text { zebra crossing. }\end{array}$ \\
\hline $\begin{array}{l}\text { Active and living } \\
\text { facades of } \\
\text { buildings. }\end{array}$ & $\begin{array}{l}\text { There were shops that were visually } \\
\text { active. }\end{array}$ & $\begin{array}{l}\text { The facade of the } \\
\text { building next to the } \\
\text { sidewalk was } \\
\text { active and alive, } \\
\text { because it was a } \\
\text { visual actived } \\
\text { shop. }\end{array}$ & $\begin{array}{l}\text { Met the criteria } \\
\text { of being active } \\
\text { and alive. }\end{array}$ & $\begin{array}{l}\text { Can be } \\
\text { maintainable. }\end{array}$ \\
\hline $\begin{array}{l}\text { Has shade and } \\
\text { protection. }\end{array}$ & $\begin{array}{l}\text { There was a tree shade and dust cover } \\
\text { on some of the sidewalks }\end{array}$ & $\begin{array}{l}\text { It does not meet the } \\
\text { criteria because } \\
\text { there were already } \\
\text { shade trees and } \\
\text { plants to protect it } \\
\text { from dust, but it }\end{array}$ & $\begin{array}{l}\text { Did not meet } \\
\text { the criteria of } \\
\text { shade and } \\
\text { protection from } \\
\text { dust. }\end{array}$ & $\begin{array}{l}\text { - Adding shade } \\
\text { trees and plants } \\
\text { in places that } \\
\text { still do not } \\
\text { exist; }\end{array}$ \\
\hline
\end{tabular}




\begin{tabular}{|c|c|c|c|c|}
\hline $\begin{array}{l}\text { Pedestrian path } \\
\text { criteria }\end{array}$ & Field conditions & Analysis & $\begin{array}{l}\text { Conclusion } \\
\text { conditions }\end{array}$ & Recommendation \\
\hline & & $\begin{array}{l}\text { was not evenly } \\
\text { distributed in all } \\
\text { places. }\end{array}$ & & $\begin{array}{l}\text { Provide arcades } \\
\text { in buildings on } \\
\text { the edge of the } \\
\text { sidewalk. }\end{array}$ \\
\hline
\end{tabular}

3. Neighborhood road type with access to Manggarai Station

This type of road includes Dr. Saharjo 1 street which has direct access to the station, and does not have access to Manggarai Terminal (figures 7, 8, and 9).

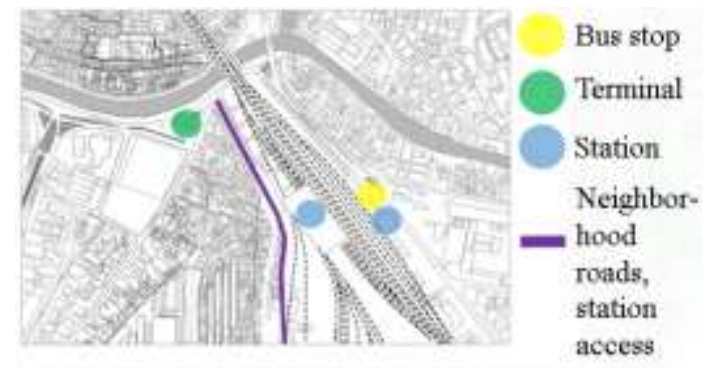

Figure 7. Map of neighborhood road location with access to stations

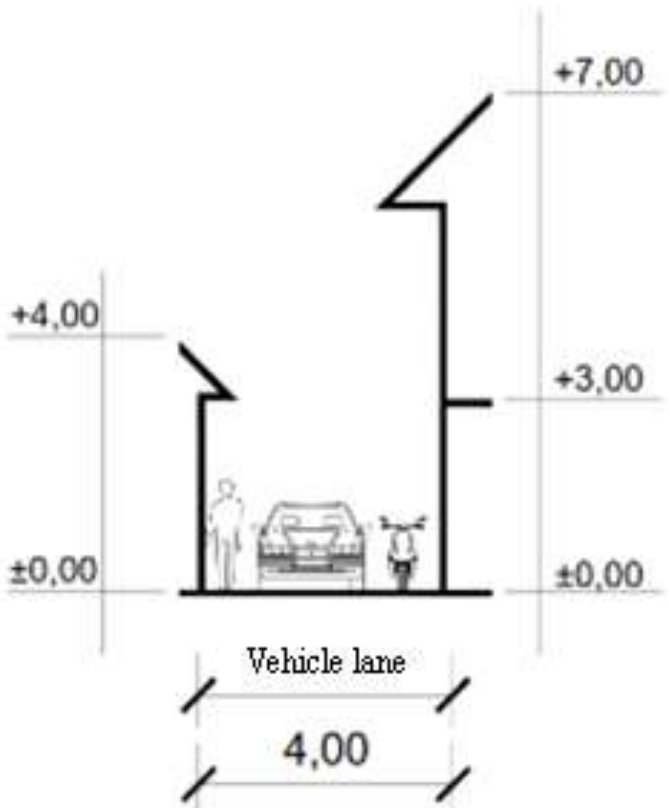

Figure 8. The road intersection on Dr. Saharjo 1 street

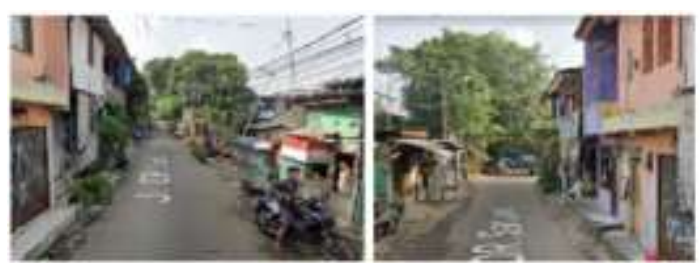

Figure 9. The atmosphere of a neighborhood road with access to the station

Table 3 showed the evaluation results of the pedestrian paths condition located in the neighborhood road with access to the station, based on the criteria set. 
Table 3. Conditions of pedestrian paths in neighborhood road types with access to stations

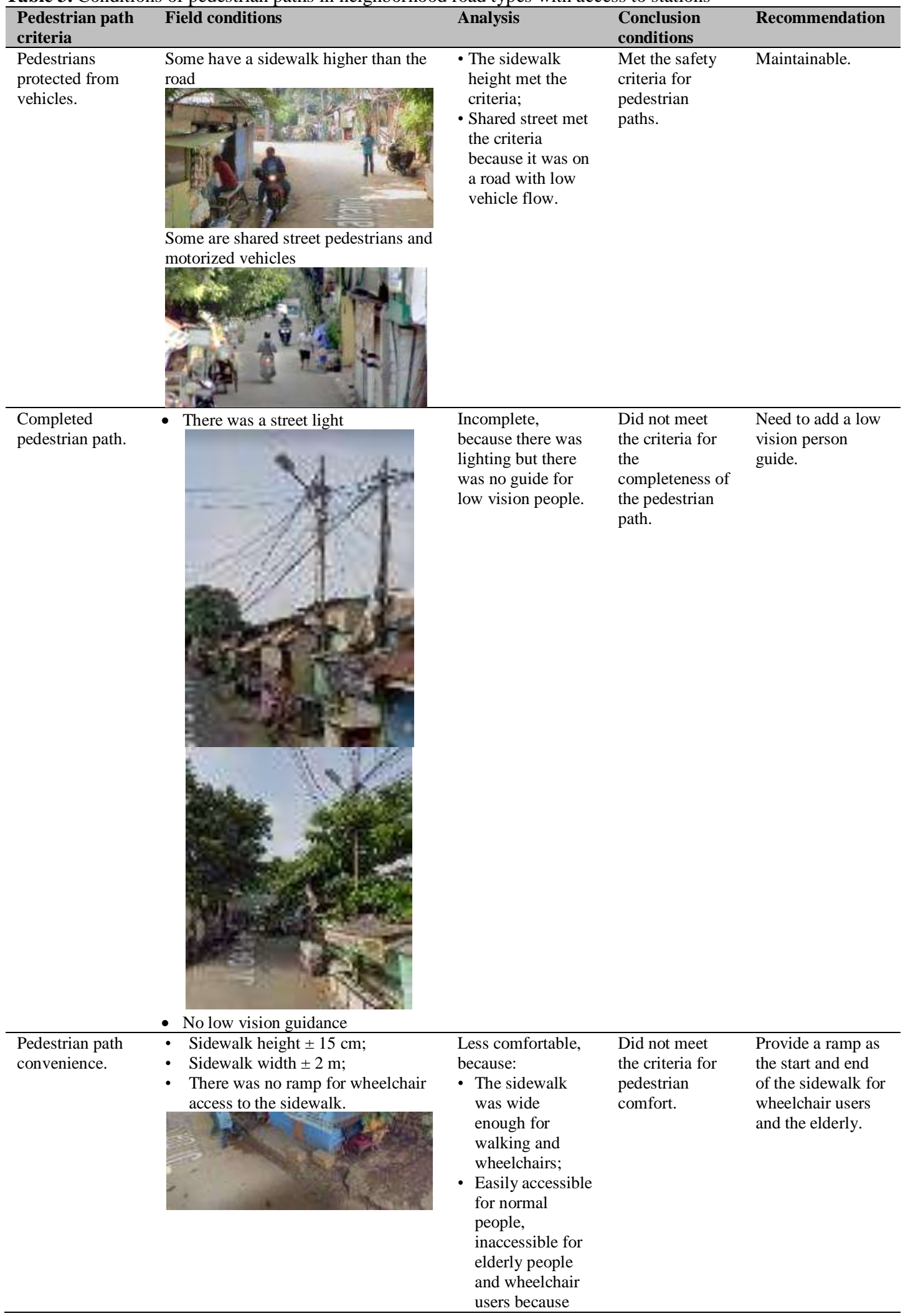




\begin{tabular}{|c|c|c|c|c|}
\hline $\begin{array}{l}\text { Pedestrian path } \\
\text { criteria }\end{array}$ & Field conditions & Analysis & $\begin{array}{l}\text { Conclusion } \\
\text { conditions }\end{array}$ & Recommendation \\
\hline & & $\begin{array}{l}\text { there was no } \\
\text { ramp. }\end{array}$ & & \\
\hline $\begin{array}{l}\text { Sidewalks were } \\
\text { unobstructed and } \\
\text { unbroken. }\end{array}$ & $\begin{array}{l}\text { - The sidewalks were blocked and } \\
\text { cut off, only } 10 \mathrm{~m} \text { long }\end{array}$ & $\begin{array}{l}\text { Sidewalks were cut } \\
\text { off and taken over } \\
\text { for other activities } \\
\text { such as trading. }\end{array}$ & $\begin{array}{l}\text { Does not meet } \\
\text { the criteria. }\end{array}$ & $\begin{array}{l}\text { Freeing } \\
\text { sidewalks from } \\
\text { activities that } \\
\text { hinder } \\
\text { pedestrian } \\
\text { circulation; } \\
\text { - Continuing on } \\
\text { the sidewalk. }\end{array}$ \\
\hline $\begin{array}{l}\text { Pedestrian } \\
\text { crossing. }\end{array}$ & There is no crossing the road facility. & $\begin{array}{l}\text { Did not meet the } \\
\text { criteria, because } \\
\text { there was no } \\
\text { crossing facilities. }\end{array}$ & $\begin{array}{l}\text { Did not meet } \\
\text { the criteria. }\end{array}$ & $\begin{array}{l}\text { Providing zebra } \\
\text { crossing especially } \\
\text { in front of the } \\
\text { Airport Train } \\
\text { Station. }\end{array}$ \\
\hline $\begin{array}{l}\text { Active and living } \\
\text { facades of } \\
\text { buildings. }\end{array}$ & $\begin{array}{l}\text { There were stalls that were visually } \\
\text { active. }\end{array}$ & $\begin{array}{l}\text { The tendency to be } \\
\text { active and alive. }\end{array}$ & $\begin{array}{l}\text { Met the criteria } \\
\text { of being active } \\
\text { and alive. }\end{array}$ & $\begin{array}{l}\text { Can be } \\
\text { maintainable. }\end{array}$ \\
\hline $\begin{array}{l}\text { Has shade and } \\
\text { protection. }\end{array}$ & $\begin{array}{l}\text { Did not have a dust filter plant. } \\
\text { Deforis }\end{array}$ & $\begin{array}{l}\text { Not meeting the } \\
\text { shading and } \\
\text { protective criteria, } \\
\text { because: } \\
\text { - Shade trees } \\
\text { were not evenly } \\
\text { distributed } \\
\text { along the road; } \\
\text { - There was no } \\
\text { dust filter but } \\
\text { the flow of } \\
\text { vehicles on this } \\
\text { road was } \\
\text { relatively low. } \\
\text { Only residents } \\
\text { and people who } \\
\text { want to go to } \\
\text { the airport train } \\
\text { station pass on } \\
\text { this road. }\end{array}$ & $\begin{array}{l}\text { Does not meet } \\
\text { the criteria. }\end{array}$ & $\begin{array}{l}\text { - Adding shade } \\
\text { trees and plants } \\
\text { in places that } \\
\text { still do not } \\
\text { exist; } \\
\text { - Provide arcades } \\
\text { in buildings on } \\
\text { the edge of the } \\
\text { sidewalk. }\end{array}$ \\
\hline
\end{tabular}


4. Residential neighborhood road type

Roads, such as Padang and Bukittinggi streets, etc., are located in a residential area, do not have access to stations or terminals (figures 10,11, and 12).

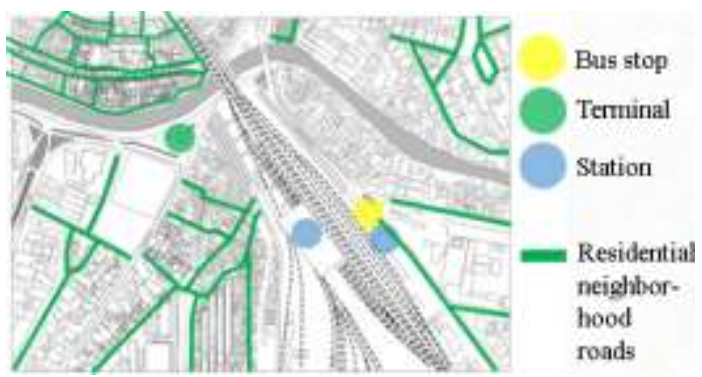

Figure 10. Map of neighborhood road locations with access to stations

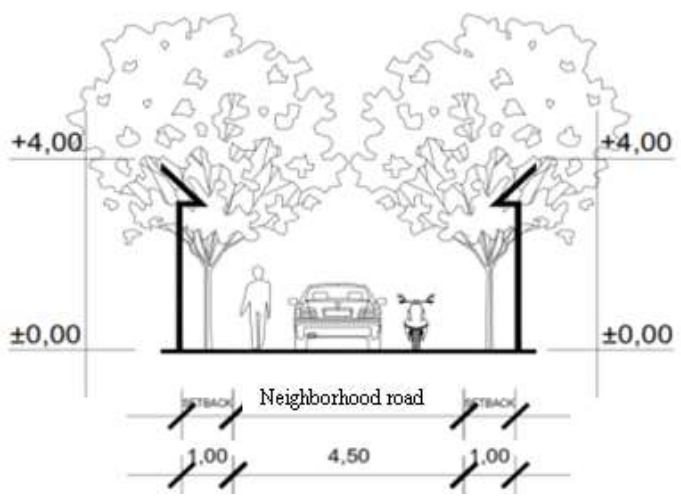

Figure 11. A section of a residential neighborhood road on Bukittinggi Street
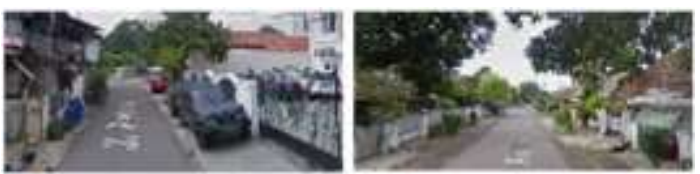

Figure 12. The street atmosphere of a residential neighborhood

Table 4 showed the evaluation results of the pedestrian paths condition in residential area, based on the criteria set.

Table 4. Pedestrian paths conditions in residential neighborhood roads

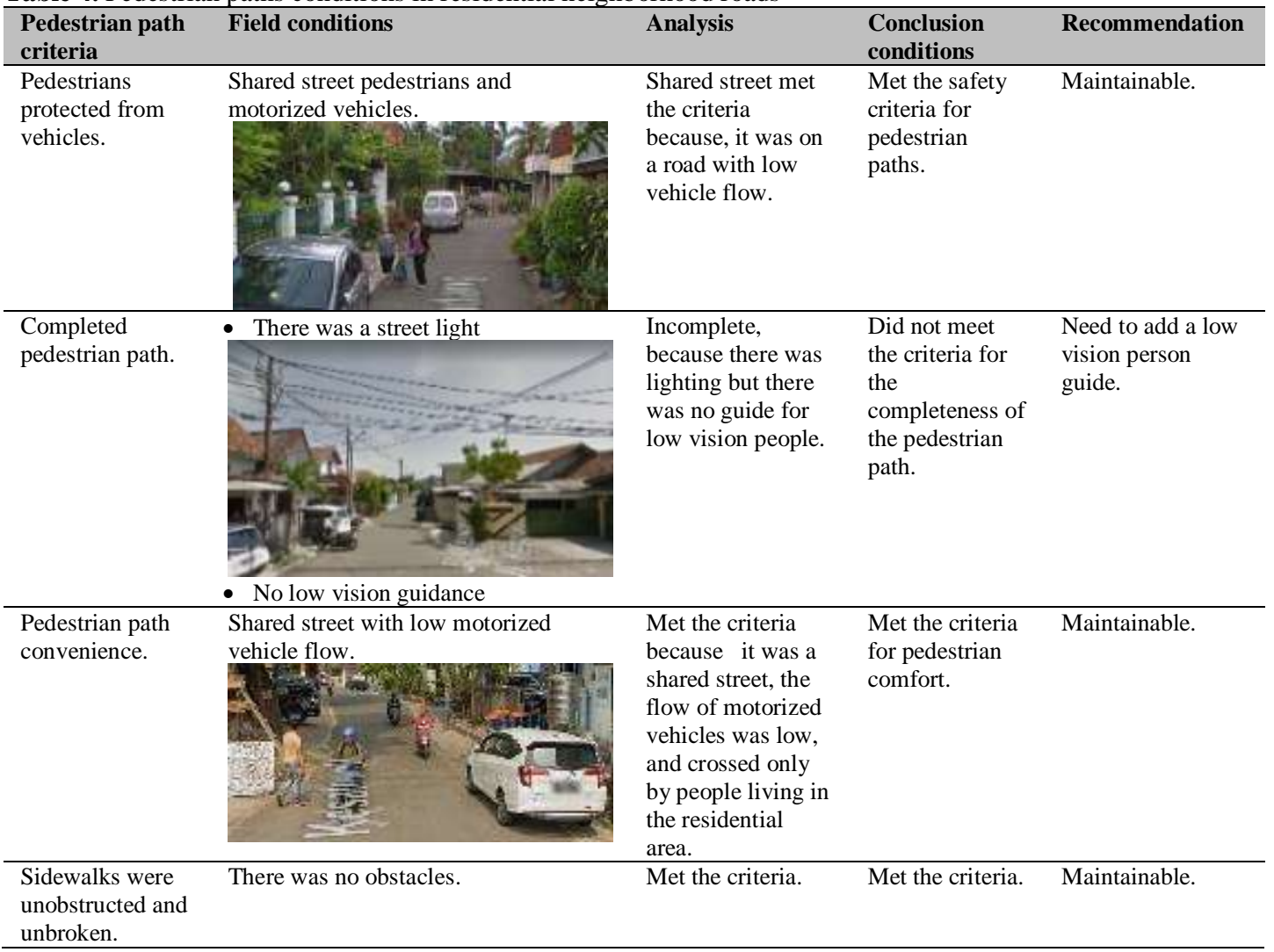




\begin{tabular}{|c|c|c|c|c|}
\hline $\begin{array}{l}\text { Pedestrian path } \\
\text { criteria }\end{array}$ & Field conditions & Analysis & $\begin{array}{l}\text { Conclusion } \\
\text { conditions }\end{array}$ & Recommendation \\
\hline $\begin{array}{l}\text { Pedestrian } \\
\text { crossing. }\end{array}$ & There was no crossing facilities. & $\begin{array}{l}\text { Met the criteria } \\
\text { because, there was } \\
\text { no crossing } \\
\text { facility, the flow of } \\
\text { vehicles on this } \\
\text { road was classified } \\
\text { as low. }\end{array}$ & Met the criteria. & Maintainable. \\
\hline $\begin{array}{l}\text { Active and living } \\
\text { facades of } \\
\text { buildings. }\end{array}$ & $\begin{array}{l}\text { The building has a set-back and was } \\
\text { bordered by a house fence. }\end{array}$ & $\begin{array}{l}\text { Not visually active } \\
\text { because it was } \\
\text { blocked by the } \\
\text { house fence. }\end{array}$ & $\begin{array}{l}\text { Did not meet } \\
\text { the criteria of } \\
\text { being active and } \\
\text { alive. }\end{array}$ & $\begin{array}{l}\text { Maintainable } \\
\text { because: } \\
\text { - This was a } \\
\text { residential } \\
\text { neighborhood } \\
\text { road only } \\
\text { passed by } \\
\text { people living in } \\
\text { the vicinity; } \\
\text { To maintain the } \\
\text { safety of the } \\
\text { houses around } \\
\text { this road and } \\
\text { provide a green } \\
\text { atmosphere. }\end{array}$ \\
\hline $\begin{array}{l}\text { Has shade and } \\
\text { protection. }\end{array}$ & Did not have a dust filter plant. & $\begin{array}{l}\text { Not meeting the } \\
\text { shading and } \\
\text { protective criteria, } \\
\text { because: } \\
\text { - Shade trees } \\
\text { were not evenly } \\
\text { distributed } \\
\text { along the road; } \\
\text { There was no } \\
\text { dust filter and } \\
\text { the flow of } \\
\text { vehicles was } \\
\text { relatively low. } \\
\text { Only local } \\
\text { residents pass } \\
\text { on this road. }\end{array}$ & $\begin{array}{l}\text { Does not meet } \\
\text { the criteria. }\end{array}$ & $\begin{array}{l}\text { Add a shade } \\
\text { tree where it } \\
\text { does not exist } \\
\text { yet. }\end{array}$ \\
\hline
\end{tabular}

\section{Conclusion}

In realizing a pedestrian path system on the implementation of the transit-oriented development concept, it is necessary to have a good cooperation from various groups, ranging from the central government, provincial, practitioners, and academics.

The following is a summary of the actions, plans or policies implemented, and needed to be carried out by stakeholders for the pedestrian route to fully support the implementation of the transit-oriented development concept in the areas around Manggarai Station, Jakarta: (1) Central Government, Making reference standards for city authorities, planners, and other related parties (Kementerian Pekerjaan Umum dan Perumahan Rakyat 2014); (2) Jakarta Provincial Government, Establishing policy targets, competency standards, Detailed Spatial Plan (RDTR), and assisting pedestrian path equipment and facilities (Kementerian Pekerjaan Umum dan Perumahan Rakyat 2014; Pemerintah Pusat DKI Jakarta 2017; Presiden Republik Indonesia 2009); (3) PT. KAI, Planning and helping to seek land acquisition for pedestrian path improvements (Pemerintah Pusat RI 2012); (4) Practitioners, Carrying out technical work under the guidelines (Kementerian Pekerjaan Umum dan Perumahan Rakyat 2014); (5) Academics, Providing direction for the draft policy in the form of an academic paper (Presiden Republik Indonesia 2003); (6) Public, Various parties should be involved in the pedestrian paths planning (Kementerian Pekerjaan Umum dan Perumahan Rakyat 2014).

Based on the results from field observations and analysis, it is concluded that, the pedestrian paths around Manggarai Station faced different 
problems, such as meeting safety criteria, unavailability of low-vision guides, less wide path, active and living conditions of the surrounding buildings, as well as a lack of shade.

The conditions observed on the field indicated that, the pedestrian path around Manggarai Station, still needs to be reorganized and improved, in order to support its function as a linkage and circulation that connects buildings, parking areas, public transportation modes, and others.

Based on the current conditions, the area around Manggarai Station needs to be arranged, in order to meet the pedestrian paths criteria, such as safety, completeness, and pedestrians' comfort, barriers and continuity, completeness of crossing facilities, as well as the availability of shade and protection for the implementation of the transitoriented development concept.

\section{References}

Alvinsyah. 2016. 'Penerapan Konsep TOD Sebagai Instrumen Penguatan Jaringan Angkutan Massal Perkotaan'. Depok. https://iutri.org/naskah-akademis/penerapankonsep-tod-sebagai-instrumen-penguatanjaringan-angkutan-massal-perkotaan.html.

Institute For Transportation And Development Policy. 2017. 'TOD Standaed'. New York City.

https://www.eltis.org/sites/default/files/traini ngmaterials/tod-2017-v3.pdf.

Jayanti, Theresia Budi. 2017. 'Kajian Eksisting Kawasan Stasiun Manggarai Terhadap Rencana Penataan Kawasan Berbasis TOD'. In Temu Ilmiah Ikatan Peneliti Lingkungan Binaan Indonesia 6, E007-E014. Ikatan Peneliti Lingkungan Binaan Indonesia. https://doi.org/10.32315/ti.6.e007.

Kementerian Pekerjaan Umum dan Perumahan Rakyat. 2014. 'Pedoman Perencanaan, Penyediaan, Dan Pemanfaatan Prasarana Dan Sarana Jaringan Pejalan Kaki'. 03/PRT/M/2014. Jakarta. https://pugpupr.pu.go.id/_uploads/Produk_Pengaturan/P ermen PUPR No 03-2014.pdf.

. 2018. 'Perencanaan Teknis Fasilitas Pejalan Kaki'. 02/SE/M/2018. Jakarta. https://binamarga.pu.go.id/uploads/files/783/ pedoman-perencanaan-teknis-fasilitaspejalan-kaki.pdf.

Mungkasa, Oswar M. 2018. 'Transit Oriented Development. Konsep-Perkembangan Terkini-Agenda Ke Depan'. In Eminar Nasional Green Architecture in the Tropic XII 'Transit-Oriented Development: Urban Planning and Design. Jakarta. https://www.researchgate.net/publication/344 072936_Transit_Oriented_Development_Ko nsep-Perkembangan_Terkini-

Agenda_Ke_Depan.

Novianto, Ari. 2016. 'Stasiun Dan Balai Yasa Manggarai, Menelisik Manggarai: Dahulu, Kini Dan Nanti'. In . Jakarta. https://docplayer.info/51736535-Stasiun-danbalai-yasa-manggarai.html.

Pemerintah Provinsi DKI Jakarta. 2012. RTRW Jakarta 2030. Indonesia. https://www.slideshare.net/inideedee/rtrwjakarta-2030-perda-prov-dki-jakarta-no1tahun-2012.

Pemerintah Pusat DKI Jakarta. 2017. Peraturan Gubernur (PERGUB) Tentang Pengembangan Kawasan Transit Oriented Development. Indonesia: BERITA DAERAH PROVINSI DAERAH KHUSUS IBUKOTA JAKARTA TA.HUN 2017 NOMOR 63003. https://peraturan.bpk.go.id/Home/Details/612 52.

Pemerintah Pusat RI. 2012. Undang-Undang (UU) Tentang Pengadaan Tanah Bagi Pembangunan Untuk Kepentingan Umum. Indonesia: LN.2012/No. 22, TLN No. 5280, LL SETNEG. https://peraturan.bpk.go.id/Home/Details/390 12.

Presiden Republik Indonesia. 2003. UndangUndang Republik Indonesia Nomor 20 Tahun 2003 Tentang Sistem Pendidikan Nasional. Indonesia.

- 2009. Undang-Undang Republik Indonesia Nomor 22 Tahun 2009 Tentang Lalu Lintas Dan Angkutan Jalan. Indonesia. https://www.dpr.go.id/dokjdih/document/uu/ UU_2009_22.pdf.

Setiawan, Agus, and Ikaputra. 2020. 'Tipologi Pengembangan Kawasan Berbasis Transit Di Kawasan Stasiun Maguwo, Yogyakarta'. ARTEKS: Jurnal Teknik Arsitektur 5 (2): 255-64. https://doi.org/10.30822/arteks.v5i2.402.

Sirait, Jhon Kalvin M., Polin D. R. Naibaho, and Emmy Ria Aritonang. 2018. 'Kajian Tentang 
Jalur Pedestrian Berdasarkan Aspek Kenyamanan'. ALUR : Jurnal Arsitektur 1 (2): $11-21$.

http://ejournal.ust.ac.id/index.php/ALUR/arti cle/view/306/pdfdd.

Wijaya, Alfred, and Sally Octaviana Sari. 2020. 'Analysis of Pedestrian Design Criteria of Padalarang Railway Station Area'. ARTEKS : Jurnal Teknik Arsitektur 5 (1): 127-34. https://doi.org/10.30822/arteks.v5i1.363.

\section{Author(s) contribution}

Muhammad Faleri Febriyanto contributed to the research concepts preparation, methodologies, investigations, data analysis, visualization, articles drafting and revisions.

Yohanes Karyadi Kusliansjah contribute to methodology, supervision, and validation.

Rumiati Rosaline Tobing contribute to the research concepts preparation and literature reviews, data analysis, of article drafts preparation and validation. 